\title{
Clean the Sprayer to Avoid Crop Injury'
}

\author{
Frederick M. Fishel ${ }^{2}$
}

The objective of this document is to present the correct clean-out procedure for spray equipment following herbicide use. This document provides guidelines for properly cleaning pesticide application equipment to prevent herbicide injury to susceptible crops. A listing of commercially available tank cleaners is also provided. The information contained in this document is not a substitute for a pesticide label.

How are susceptible plants injured by herbicides? Herbicides can damage crops in many ways, including:

- Applying the wrong herbicide can damage susceptible crops.

- Herbicide drift from nearby applications.

- Excessive water runoff containing herbicides.

- Applicators not following the application directions specified on product labels.

- Applications made under abnormal environmental conditions.

- Applicators that do not thoroughly clean sprayer equipment before spraying different crops. Many product labels will provide specific directions for removing their products' residues from spray equipment (Figure 1).

\section{Sprayer Clean-Out}

To avoid injury to desirable plants, thoroughly clean equipment used to apply this product before using it to apply other chemicals.

For glyphosate-tolerant corn:

If the crop following the application of Enlist Duo is an application to glyphosate-tolerant corn, rinse the spray equipment with clean water at least $10 \%$ of the total tank volume.

For all other crops:

1. Completely drain the spray system, including pump, lines and spray boom, for at least 5 minutes.

2. Fill the spray tank with clean water to at least $10 \%$ of the total tank volume and circulate the solution through the entire system so that all internal surfaces are contacted for at least 15 minutes to complete the first rinse of the application equipment. Spray the solution out of the spray tank through the boom.

3. Completely drain the spray system, including lines and spray boom, for at least 5 minutes; remove and clean filters and strainers.

4. During the second rinse, fill the container with clean water. The addition of tank cleaning agents may be used at the manufacturer's recommended rates. Circulate the solution through the entire system for at least 15 to 20 minutes. Let the solution stand for several hours, preferably overnight. Spray the solution out of the spray tank through the boom.

5. Completely drain the spray system, including lines and spray boom, for at least 5 minutes.

6. Fill the container with clean water to at least $10 \%$ of the total tank volume and circulate the solution through the entire system so that all internal surfaces are contacted for at least 15 minutes to complete the third rinse of the application equipment. Spray the solution out of the spray tank through the boom.

7. Completely drain the spray system, remove nozzle tips and strainers and clean them separately.

Figure 1. Label directions for sprayer clean-out. Credits: CDMS

\section{Why is there a premium placed on sprayer cleanout} today? Many of today's herbicides are active at very low rates. Even when there are only small amounts of herbicides left in the spray system, thousands of dollars in damage can potentially occur. Also, herbicide-tolerant crops that allow certain nonselective or broad-spectrum herbicides to kill weeds without injury to the crop have been developed (Figure 2).

1. This document is PI277, one of a series of the Agronomy Department, UF/IFAS Extension. Original publication date August 2018. Visit the EDIS website at http://edis.ifas.ufl.edu.

2. Frederick M. Fishel, professor, Agronomy Department; UF/IFAS Extension, Gainesville, FL 32611.

The Institute of Food and Agricultural Sciences (IFAS) is an Equal Opportunity Institution authorized to provide research, educational information and other services only to individuals and institutions that function with non-discrimination with respect to race, creed, color, religion, age, disability, sex, sexual orientation, marital status, national origin, political opinions or affiliations. For more information on obtaining other UF/IFAS Extension publications, contact your county's UF/IFAS Extension office. 


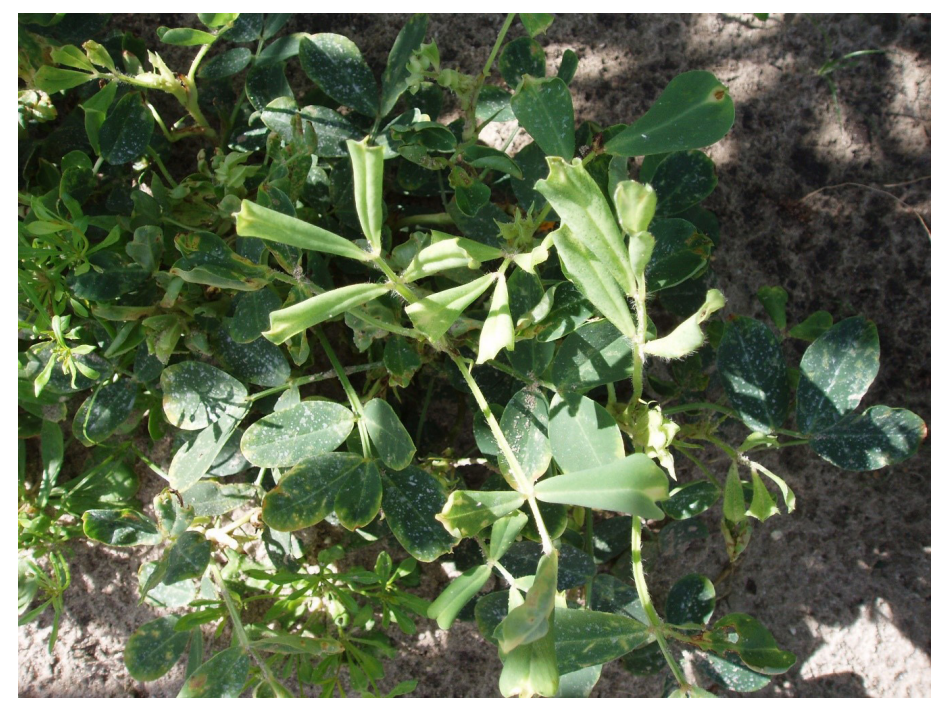

Figure 2. Dicamba injury to peanut caused by residues remaining in the sprayer.

Credits: UF/IFAS Pesticide Information Office

Dry formulations of herbicides, including dry flowables and water-dispersible granules, have increased in popularity; however, when applicators fail to allow enough mixing time, larger particles of the dry product can get trapped in a series of screens. The particles may remain in the sprayer system until applicators run enough water through the screens or another product solubilizes them into smaller pieces, which can then pass through the screens and out the nozzles.

The use of adjuvants with postemergence herbicides is a common practice, because many products' directions for use call for their use to improve performance. Adjuvants may also dislodge old herbicide residues that are embedded in tank walls or hoses, or they may help break down particles in screens. When they do, the adjuvants may cause an old, unwanted herbicide residue to be part of the spray liquid.

As glyphosate-resistant weed populations have grown, it has become common to use multiple herbicides to control resistant weeds. It is important, of course, to learn which herbicides can be tank-mixed to control these resistant weeds. This practice also makes cleaning application equipment between sprays more important than ever.

Modern sprayers can have complicated plumbing that is interconnected. Such plumbing can have many places where herbicide residues remain trapped, even after flushing hundreds or thousands of gallons of water through the system. Although flushing the system with clean water will remove most remaining herbicides from the system, clean water will not remove it all. This increases the probability that those residues may be applied to a susceptible crop.
Several products that recently received EPA registration are specifically designed to be applied to herbicide-tolerant crops. As part of the registration requirements, the manufacturers include very strict and specific guidance in their product labels for spray equipment cleanout procedures. Confirmation of spray system equipment cleaning is a mandatory element in the required records to be maintained by applicators of these products.

\section{Are there certain parts of the sprayer system that are problematic for residue collection? Hoses, booms and their end caps, screens, and the tank itself can all pose as collection points for herbicide residues.}

Hoses can be difficult to clean adequately for several reasons. Those constructed of rubber that has become cracked can hold residues embedded in the cracks. Mississippi State University research shows that when applicators leave herbicides overnight in rubber hoses, the herbicide can penetrate and reside in the hoses and ultimately become more difficult to remove. Another potential problem with hoses is that some may sag between connection points, allowing for residue collection.

Booms can be challenging to thoroughly flush because once the tank is empty, the pump loses its prime, thus lacks pressure to adequately force out all spray solution. The tank has to be filled with clean water to reprime the pump for forcing out any leftover spray. Boom end caps that have not been removed and cleaned can have buildup of paste containing significant herbicide residues.

Screens and strainers filter various debris; however, dry formulations that have not been adequately agitated can also become trapped in them (Figure 3). Always remove the screens and strainers, then inspect them for debris accumulation; clean if necessary.

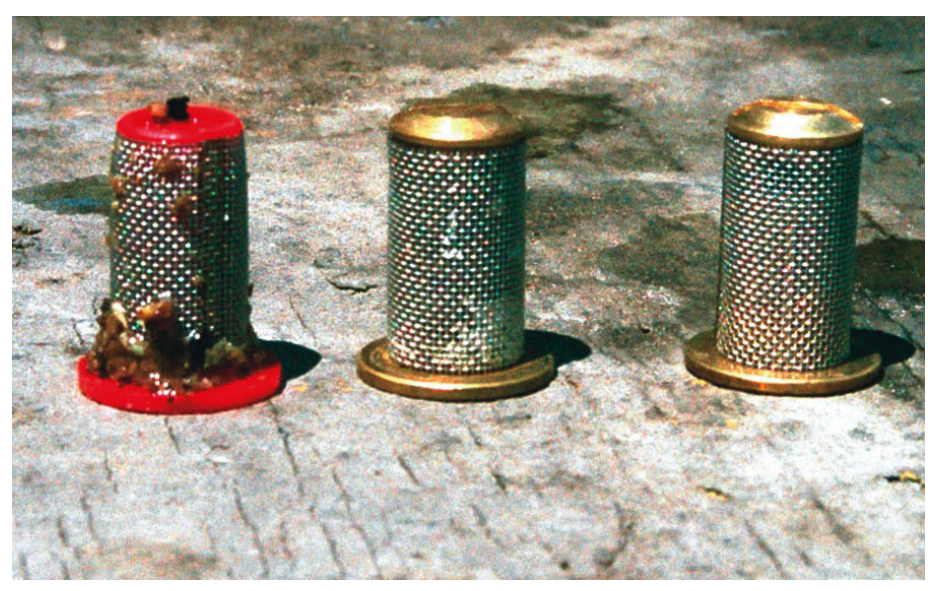

Figure 3. Debris-clogged nozzle tip screens (left and center); clean screen (right).

Credits: UF/IFAS Pesticide Information Office 
The design of the tank can determine how much spray solution remains in its bottom. Ideally, the tank should have a sloped bottom surface with the drain opening slightly above the sump. If the tank contains baffles, residue can accumulate at bases of baffles. The tank's interior surface is another point of residue collection. Without cleaning its interior surface, herbicide residue can be present in the next load of spray mix. There are commercially available tank-cleaning nozzles that rotate with the flow of water to provide $360^{\circ}$ coverage of the inside surfaces of the tank.

\section{If the product I was applying has label directions to use} a sprayer cleaner when flushing out the system, which should I use? Some label directions will specify. There are three primary types:

- Commercial tank cleaners

- Household ammonia

- Chlorine bleach

Sprayer cleaning agents perform three basic functions: to neutralize (that is, deactivate) the herbicide molecule, to increase the herbicide's solubility, so it can be flushed more easily, and to remove any residues that may have penetrated the walls of hoses, tanks, or fittings.

Household ammonia is commonly recommended by product labels as a cleaning agent. It's effective at penetrating and loosening deposits in the spraying system. Although ammonia does not deactivate herbicides, it increases the solubility of some herbicides by raising the $\mathrm{pH}$ of the rinsate in the system.

Chlorine bleach can deactivate pesticide residues. It is sometimes recommended for cleaning out sprayer systems. A precaution to keep in mind if using chlorine bleach is that it can combine with ammonia-containing fertilizers to produce dangerous chlorine gas, which is irritating to the eyes, nose, throat, and lungs. DO NOT, under any circumstances, mix household ammonia with chlorine bleach for any cleaning purpose.

There are so many commercial-grade spray system cleaners, how do I decide which to use? There are several aspects to ask for in cleaner selection, including:

- Does it increase and hold rinsate $\mathrm{pH}$ levels above $\mathrm{pH} 12$ ? This facilitates the chemical breakdown of herbicides that are vulnerable to alkaline hydrolysis and solubilizes residues for better rinsing.
- Does it contain detergents to penetrate and remove driedon residues?

- Does it include surfactants to emulsify oil residues that can serve as anchoring sites for other oil-soluble herbicides?

- Does it protect equipment from corrosion by including corrosion inhibitors in the formulation?

See Table 1 for available commercial cleaners, manufacturers, and comments of interest.

What is a step-by-step procedure for general spray system cleanout? These are general guidelines; always consult the label as the best source of specific cleaning information for the product. This is especially important for products that will be used for application to herbicide-tolerant crops.

1. Completely spray out mixture from the sprayer. Do not allow spray mixture to sit overnight.

2. Clean all strainers, filters, nozzles and their screens, diaphragms, and boom caps (where residues tend to accumulate).

3. Precisely follow the directions for the cleaner or the procedures listed on the herbicide label. Any ratio of cleaner to water less than the label instructions will result in insufficient cleanout.

4. Agitate the mixture for 5 to 10 minutes. Then charge pumps, hoses, and nozzles by spraying a small amount of solution through the sprayer; ensure the solution is spraying out of the nozzles.

5. Shut off the sprayer, keeping the hoses and nozzles charged.

6. Refill the tank with the labeled ratio of cleaner to water.

7. Let the spray system sit a minimum of 12 hours unless otherwise stated on the label.

8. Following soaking, spray the solution through the boom for 10 minutes and then drain remaining solution until the sprayer is empty.

9. Flush spray tank with clean water and empty. Check all strainers, filters, nozzles, and screens, as this process can free residue from the sprayer.

10. Clean and rinse the exterior of the sprayer. 
11. Appropriately dispose of all rinsate in compliance with local, state, and federal requirements.

\section{Additional Information}

Cundiff, G.T., D.B. Reynolds, and T.C. Mueller. 2017.

"Evaluation of dicamba persistence among various agricultural hose types and cleanout procedures using soybean (Glycine max) as a bio-indicator." Weed Sci. 65: 305-316.

Young, B. G., J. L. Matthews, and F. Whitford. 2016. Compendium of Herbicide Adjuvants. PPP-115. Purdue Pesticide Programs. 
Table 1. Tank cleaners and/or neutralizers.

\begin{tabular}{|c|c|c|c|}
\hline Product & Manufacturer/distributor & Principal functioning agent & Comments \\
\hline All Clear & $\begin{array}{l}\text { Loveland Products, Inc. } \\
\text { www.cpsagu.com }\end{array}$ & Surfactants, sequestrants, degradants & Cleans and decontaminates \\
\hline $\begin{array}{l}\text { Brandt Pesticide } \\
\text { Equipment Cleaner }\end{array}$ & $\begin{array}{l}\text { Brandt Consolidated, Inc. } \\
\text { www.brandtconsolidated.com }\end{array}$ & $\begin{array}{l}\text { Potassium hydroxide, anticorrosion, } \\
\text { sequestrant, nonionic and ionic } \\
\text { surfactants, polydimethylsiloxane }\end{array}$ & \\
\hline Chempro TN-610 & $\begin{array}{l}\text { Chemorse, Ltd. } \\
\text { www.chemorse.com }\end{array}$ & Surfactants, dispersants, emulsifiers & \\
\hline $\begin{array}{l}\text { Cornbelt Tank } \\
\text { Cleaner-Dry }\end{array}$ & \multirow{2}{*}{$\begin{array}{l}\text { Van Diest Supply Co. } \\
\text { www.vdsc.com } \\
\text { Van Diest Supply Co. } \\
\text { www.vdsc.com }\end{array}$} & \multirow{2}{*}{$\begin{array}{l}\text { Complex phosphates, sodium silicate, } \\
\text { sodium hydroxide, sodium carbonate, } \\
\text { monocyclic terpenes, nonionic } \\
\text { surfactant }\end{array}$} & \\
\hline $\begin{array}{l}\text { Cornbelt Tank } \\
\text { Cleaner-Liquid }\end{array}$ & & & \\
\hline Delete-It & $\begin{array}{l}\text { Plant Health Technologies } \\
\text { www.simplot.com }\end{array}$ & Not specified & Elevates rinsate $\mathrm{pH}$ \\
\hline Elite Vigor & $\begin{array}{l}\text { Red River Specialties, Inc. } \\
\text { www.rrsi.com }\end{array}$ & $\begin{array}{l}\text { Anionic surfactants, ammonia, } \\
\text { sequestrants }\end{array}$ & \\
\hline Erase & $\begin{array}{l}\text { Precision Laboratories, LLC } \\
\text { www.precisionlab.com }\end{array}$ & $\begin{array}{l}\text { Proprietary blend of alkalinity builders, } \\
\text { emulsifiers, surfactants, and formulation } \\
\text { aids }\end{array}$ & $\begin{array}{l}\text { Elevates rinsate } \mathrm{pH} \text { to degrade } \\
\text { vulnerable crop protection } \\
\text { products }\end{array}$ \\
\hline FS CleanSupreme & \multirow[t]{2}{*}{$\begin{array}{l}\text { Growmark, Inc. } \\
\text { www.growmark.com }\end{array}$} & $\begin{array}{l}\text { Proprietary blend of alkalinity builders } \\
\text { and detergents }\end{array}$ & \\
\hline FS RinseOut & & $\begin{array}{l}\text { Blend of alkalinity builders, emulsifiers, } \\
\text { surfactants, and formulation aids }\end{array}$ & May require anti-foam \\
\hline Incide-Out & $\begin{array}{l}\text { Precision Laboratories, LLC } \\
\text { www.precisionlab.com }\end{array}$ & $\begin{array}{l}\text { Proprietary blend of alkalinity builders, } \\
\text { detergents, and anti-redeposition } \\
\text { agents }\end{array}$ & DuPont and Syngenta approved \\
\hline $\begin{array}{l}\text { Innvictis Premium } \\
\text { Tank Cleaner }\end{array}$ & $\begin{array}{l}\text { Innvictis Crop Care, LLC } \\
\text { www.innvictis.com }\end{array}$ & $\begin{array}{l}\text { Organic amine, inorganic hydroxides, } \\
\text { surfactants, and formulation aids }\end{array}$ & \\
\hline K-Klean & $\begin{array}{l}\text { KALO, Inc. } \\
\text { www.kalo.com }\end{array}$ & $\begin{array}{l}\text { Cleaning agents in a proprietary } \\
\text { transparent emulsion }\end{array}$ & Economical liquid tank cleaner \\
\hline $\begin{array}{l}\text { Kleen-Up Liquid Tank } \\
\text { Cleaner }\end{array}$ & $\begin{array}{l}\text { Rosen's, Inc. } \\
\text { www.aginfotoday.com }\end{array}$ & $\begin{array}{l}\text { Nonionic and amphoteric surfactants, } \\
\text { chelating and emulsifying agents, } \\
\text { monoethanolamine, inorganic } \\
\text { hydroxides, and formulation aids }\end{array}$ & $\begin{array}{l}\text { Approved for cleaning all } \\
\text { pesticides and pesticide residues }\end{array}$ \\
\hline $\begin{array}{l}\text { Protank Liquid } \\
\text { Cleaner }\end{array}$ & $\begin{array}{l}\text { Winfield Solutions, LLC } \\
\text { www.winfield.com }\end{array}$ & Proprietary blend & \\
\hline Purge & $\begin{array}{l}\text { AgXplore International, Inc. } \\
\text { www.agxplore.com }\end{array}$ & $\begin{array}{l}\text { Sodium metasilicate, inorganic } \\
\text { hydroxides, surfactants, and formulation } \\
\text { aids }\end{array}$ & \\
\hline Purus & $\begin{array}{l}\text { United Suppliers, Inc. } \\
\text { www.unitedsuppliers.com }\end{array}$ & $\begin{array}{l}\text { Blend of alkalinity builders, emulsifiers, } \\
\text { surfactants, and formulation aids }\end{array}$ & Elevates rinsate $\mathrm{pH}$ \\
\hline Remove & $\begin{array}{l}\text { GarrCo Products Inc. } \\
\text { www.garrco.com }\end{array}$ & $\begin{array}{l}\text { Proprietary concentrated blend of } \\
\text { buffering agents, detergents, and } \\
\text { functioning cleaners }\end{array}$ & $\begin{array}{l}\text { Allow sufficient time for the } \\
\text { cleaning solution to penetrate } \\
\text { the residue }\end{array}$ \\
\hline $\begin{array}{l}\text { Tank \& Equipment } \\
\text { Cleaner }\end{array}$ & $\begin{array}{l}\text { Brewer International } \\
\text { www.brewerint.com }\end{array}$ & $\begin{array}{l}\text { Solvent type detergent and other } \\
\text { ingredients }\end{array}$ & High pH \\
\hline $\begin{array}{l}\text { Tank and Equipment } \\
\text { Cleaner }\end{array}$ & $\begin{array}{l}\text { Loveland Products, Inc. } \\
\text { www.cpsagu.com }\end{array}$ & Detergent mixture & $\begin{array}{l}\text { Cleans and neutralizes } \\
\text { equipment }\end{array}$ \\
\hline $\begin{array}{l}\text { Tank and Equipment } \\
\text { Cleaner }\end{array}$ & $\begin{array}{l}\text { Rosen's, Inc. } \\
\text { www.aginfotoday.com }\end{array}$ & $\begin{array}{l}\text { Complex phosphates, sodium silicate, } \\
\text { sodium hydroxide, sodium carbonate, } \\
\text { monocyclic terpenes, and nonionic } \\
\text { surfactant }\end{array}$ & Approved by Syngenta \\
\hline
\end{tabular}




\begin{tabular}{|c|c|c|c|}
\hline Product & Manufacturer/distributor & Principal functioning agent & Comments \\
\hline Tank Cleaner & $\begin{array}{l}\text { KALO, Inc. } \\
\text { www.kalo.com }\end{array}$ & $\begin{array}{l}\text { Complex phosphates, sodium sulfate, } \\
\text { sodium carbonate, sodium hydroxide, } \\
\text { monocyclic terpenes, NIS }\end{array}$ & $\begin{array}{l}\text { Dry tank cleaner with dye to } \\
\text { identify rinsate }\end{array}$ \\
\hline Warsh-Out & $\begin{array}{l}\text { Drexel Chemical Co. } \\
\text { www.drexchem.com }\end{array}$ & $\begin{array}{l}\text { Alkalinity builders, surfactants, anti- } \\
\text { redeposition aid, corrosion inhibitor, } \\
\text { formulation aids }\end{array}$ & Low use rates \\
\hline Wipe Out & $\begin{array}{l}\text { Helena Chemical Co. } \\
\text { www.helenachemical.com }\end{array}$ & Blend of proprietary surfactants & $\begin{array}{l}\text { Effective for sulfonylurea } \\
\text { herbicide tank cleaning }\end{array}$ \\
\hline Work-Horse & $\begin{array}{l}\text { Atlantic Pacific Agricultural, Inc. } \\
\text { www.atlantic-pacificag.com }\end{array}$ & Not provided & $\begin{array}{l}\text { Use up to } 4 \text { qts for difficult } \\
\text { chemical build-up }\end{array}$ \\
\hline
\end{tabular}

